\title{
Community Pressure and Environmental Compliance: Case of Rubber Processing in Sri Lanka
}

\author{
J. C. Edirisinghe \\ Dept. of Agribusiness Management, \\ Faculty of Agriculture \& Plantation Management, \\ Wayamba University of Sri Lanka, \\ Makandura, Gonawila (NWP), Sri Lanka
}

Tel: (94) 31229 9246: Fax: (94) 31229 9246: E-mail: jagathed@yahoo.com

\begin{abstract}
This study uses data from rubber processing factories in Sri Lanka to identify the impact of informal regulation on environmental compliance. Unlike earlier studies, this study looks at three pollution measures; Chemical Oxygen Demand (COD), Biological Oxygen Demand (BOD) and Total Suspended Solids (TSS) in a simultaneous analysis taking into account the potential correlation of the residuals if these equations are estimated separately. The results suggest that formal regulation play a minor role in making factories complying with environmental standards. However, there are significant gains to be made through informal regulation in this sector.
\end{abstract}

KEYWORDS: Informal regulation, Command and control, Water pollution, Seemingly Unrelated Regression

\section{Introduction}

According to the Central Environmental Authority (CEA) of Sri Lanka, Rubber processing is categorized as one of the major polluting industries in Sri Lanka (Ranaweera, 1991). On the average, a production of one kilogram of rubber discharges approximately 40-50 litres of effluent. Thus, according to the total production of 114,700 Metric Tonnes (IRSG, 2007) in 2006, an effluent load of 4.5 to 5.7 billion litres has been produced and discharged to the natural ecosystem.

The three main grades of natural rubber produced in Sri Lanka are Ribbed Smoked Sheets (RSS), Crepe rubber and centrifuged latex. The effluent generated by such production contains 30-40 percent of rubber and 60-70 percent of serum substances. These serum substances contain amino acids, carbohydrates and plant growth substances with lactic acid which is formed in the latex. The chemicals added in the production process of rubber are also present in the serum. These include among others, sodium sulphite, ammonia or formalin formic, acetic, oxalic acid sodium 
bisulphite, metabisulphite and xylyl mercaptan. Water contaminated such an effluent cannot be used for any other domestic or industrial purposes (Kudaligama et al, 2004), and these effluents have been found to also pollute groundwater (Dan, Thanh and Truong, 2006; Kudaligama et al, 2004).

Yapa (1984) reported that about 50 percent of the rubber factories in operation in Sri Lanka do not have facilities to treat effluent before discharging it to the ecosystem. After more than two decades, another study by Edirisinghe et al, (2008) reports a similar figure of environmental non-compliance by the natural rubber processing industry in Sri Lanka and proposes a Pigouvian tax system to combat the issue. While noting that the command and control system prevailing in the country have failed in completely eradicating the environmental non-compliance, it is observed that some factories attempts to comply with the environmental standards set out by the CEA of Sri Lanka.

Thus, it is worthwhile investigating into the reasons for environmental compliance by these factories even without a pollution tax in place. Using the data from 62 operational rubber processing factories in Sri Lanka, this study attempted to identify reasons for environmental compliance in the rubber industry in Sri Lanka.

\section{Methodology}

\section{Previous Literature on Water Pollution}

Water pollution studies span into different areas in different countries. Murty et al (2001) looked into water pollution in the sugar industry in India while Goldar et al (2001) have concentrated on distilleries in India. A study by Dasgupta et al (2001) uses data from food processing, textiles, paper, oil refining and chemical industries in China. Pargal and Wheeler (1996) studied the organic water pollution industries in Indonesia. Huq and Wheeler (1993) Hartman, Huq and Wheeler (1994)

Pargal and Wheeler (1996), Kathuria, (2004) have shown that informal regulation play a major role in making factories comply with environmental standards. Hartman, Huq and Wheeler (1994) identify three sets of factors that affect pollution intensity of an industrial process. These include, plant characteristics, economic considerations and external pressure. They have constructed an abatement effort score which was used as the dependent variable in assessing the factors affecting pollution intensity.

Pargal and Wheeler (1996) in their study used Biological Oxygen Demand (BOD) as the measure of pollution stating that it is the most common regulated water pollutant. They have regressed the total BOD load with demand variables (output, wage, and fuel price), firm variables (value added for worker, ownership status) and variables relating to informal regulation (income per capita, local employment 
share, education and population density) with dummies to represent the industrial sector the factories belong to.

\section{Model}

Unlike earlier studies, this study used three pollutants in a simultaneous analysis. Data collection included the measurement of quality of effluent waters of each factory on BOD, COD and TSS. Therefore, the econometric model can be specified as;

$$
Y_{i j}=f\left(X_{n j}\right)+u_{j}
$$

Where, $i=1,2,3$ and $j=1 \ldots . J$

The term $Y_{i j}$ refers to the concentration of the $i^{\text {th }}$ pollutant of the $j^{\text {th }}$ firm. $X_{n j}$ is the $n^{\text {th }}$ variable affecting the pollution intensity of the $j^{\text {th }}$ firm and the term $u_{\mathrm{j}}$ captures the error of the $i^{\text {th }}$ firm. Since there are three type of pollutants (BOD, COD and TSS) measured in this study, equation (1) refers to a system of three equations. The exogenous variables in these three equations are similar while the endogenous variables are different from each other due to the presence of three pollutants. Controlling one of these pollutants has an impact on the others. Thus, estimating these three equations separately is not efficient as error terms may be correlated. Zellner (1962) proposed the 'Seemingly Unrelated Regression' (SUR) Model for such situations. Accordingly, this model can be specified as,

$$
\begin{aligned}
& Y_{1 j}=X_{1} \beta_{1}+u_{1 j} \\
& Y_{2 j}=X_{2} \beta_{2}+u_{2 j} \\
& Y_{3 j}=X_{3} \beta_{3}+u_{3 j}
\end{aligned}
$$

Where, $Y_{1 j}, Y_{2 j}$ and $Y_{3 j}$ refer to COD, BOD and TSS load in the $j^{\text {th }}$ factory. $\mathrm{X}$ is a matrix of variables that influence the pollution intensity of COD, BOD and TSS (Table 1). Because vectors of $\beta$ is different in each equation, they appear to be independent. However, errors in the equations correlate with each other and provide links that can be exploited in estimation (Wooldridge, 2001). Yet, errors in each equation are assumed to be independent of the explanatory variables in all equations.

\section{Data and Variables}

There were a total of 104 rubber processing factories in Sri Lanka. However, due to the cost minimizing policies, these factories have opted for 'central processing', where, natural rubber produced in different parts of the country has been transported 
to a central location for processing. This had made some of the processing plants to be not in operation. The survey covered 62 such plants that are in operation. The data collected pertain to the year 2005. The Chemical Oxygen Demand (COD) and Total Suspended Solids (TSS) and BOD of waste water samples were analyzed in the laboratories of the Rubber Research Institute of Sri Lanka. The description of variables used in the analysis is given in Table 1.

Table 1: Description of variables

\begin{tabular}{|c|c|}
\hline Variable & Description \\
\hline BOD load & Amount of BOD levels in kilogram discharged as effluent \\
\hline COD load & Amount of COD levels in kilogram discharged as effluent \\
\hline TSS load & Amount of TSS levels in kilogram discharged as effluent \\
\hline Visits & $\begin{array}{l}\text { Number of visits made by CEA officials during the year. } \\
\text { This is included as a proxy for the effort in command and } \\
\text { control system prevailing in the country }\end{array}$ \\
\hline $\mathrm{TP}$ & $\begin{array}{l}\text { Total production of rubber in the factory during the year. } \\
\text { Pollution load is expected to increase with the output }\end{array}$ \\
\hline \multirow[t]{3}{*}{ Type } & $\begin{array}{l}\text { Dummy variable representing the type of natural rubber } \\
\text { produced. }\end{array}$ \\
\hline & $1=$ if the firm produces centrifuged latex; \\
\hline & $0=$ otherwise \\
\hline \multirow[t]{3}{*}{ Complain } & $\begin{array}{l}\text { Dummy variables representing the community pressure for } \\
\text { abatement. It expected that the community pressure will } \\
\text { increase abatement }\end{array}$ \\
\hline & $1=$ if there was a complain on pollution \\
\hline & $0=$ otherwise \\
\hline
\end{tabular}

\section{Results and Discussion}

A total of 62 factories were surveyed in 6 districts in the country as given in Table 2. These were the total number of factories that were in operation at the time of data collection. As expected, the majority of the processing units that were in operation were found in the Kalutara district as it is the main rubber growing district in the country. The descriptive statistics of the variables studied are given in Table 3. 
Table 2: Location of factories

\begin{tabular}{cc}
\hline District & No. of Factories Studied \\
\hline Kalutara & 26 \\
Kegalle & 12 \\
Ratnapura & 12 \\
Colombo and Gampaha & 6 \\
Galle & 6 \\
Total & $\mathbf{6 2}$ \\
\hline
\end{tabular}

Table 3: Descriptive statistics

\begin{tabular}{ccccc}
\hline & Unit & Minimum & Average & Maximum \\
\hline $\begin{array}{c}\text { Total cost of } \\
\text { production/annum } \\
\text { Turnover/annum }\end{array}$ & $\begin{array}{c}\text { Million } \\
\text { LKR }\end{array}$ & 1.03 & 38 & 392 \\
$\begin{array}{c}\text { Million } \\
\text { LKR }\end{array}$ & 0.98 & 210 & 7429 \\
$\begin{array}{c}\text { Wastewater } \\
\text { volume/annum }\end{array}$ & Kilolitres & 914 & 24664 & 155977 \\
Effluent Characteristics & & & & \\
BOD & $\mathrm{mg} / 1$ & 2 & 1062.5 & 5100 \\
COD & $\mathrm{mg} / 1$ & 20 & 2010 & 8800 \\
TSS & $\mathrm{mg} / 1$ & 4 & 242.9 & 860 \\
PH & & 1.6 & 5.9 & 8.1 \\
\hline
\end{tabular}

Note: LKR=Sri Lankan rupees

Source: Field survey

It is evident from Table 3 that the waste water volume generated by rubber producing factories in Sri Lanka varies in a significant manner. In addition, the scale of operation is also found to have a high variation as evident by the total cost of production. It is also noteworthy that mean effluent characteristics of factories are above the national standards set by the Central Environmental Authority (Table $4)$. 
Table 4: General standards and tolerance limits set by CEA

\begin{tabular}{|c|c|c|c|c|c|}
\hline \multirow{2}{*}{$\begin{array}{l}\text { Receiving } \\
\text { Substrate or } \\
\text { Medium }\end{array}$} & \multicolumn{5}{|c|}{ Tolerance limits } \\
\hline & & $\begin{array}{l}\text { BOD } \\
(\mathrm{mg} / \mathrm{l})\end{array}$ & $\begin{array}{l}\text { COD } \\
(\mathrm{mg} / \mathrm{l})\end{array}$ & pH & $\begin{array}{c}\text { TSS } \\
(\mathbf{m g} / \mathbf{l})\end{array}$ \\
\hline $\begin{array}{l}\text { Inland surface } \\
\text { waters }\end{array}$ & & 30 & 250 & $6.0-8.5$ & 50 \\
\hline CETP & & 200 & 600 & $6.0-8.5$ & 500 \\
\hline $\begin{array}{c}\text { Marine coastal } \\
\text { areas }\end{array}$ & & 100 & 250 & - & 150 \\
\hline $\begin{array}{l}\text { Textile industries } \\
\text { to inland surface } \\
\text { waters }\end{array}$ & & 60 & 250 & $6.5-8.5$ & 50 \\
\hline Irrigation purposes & & 250 & - & $5.5-9.0$ & $\begin{array}{r}2100 \\
\text { (TDS) }\end{array}$ \\
\hline & $\begin{array}{c}\text { Latex } \\
\text { concentrate }\end{array}$ & 60 & 400 & $6.5-8.5$ & 100 \\
\hline $\begin{array}{l}\text { Rubber to inland } \\
\text { surface waters }\end{array}$ & $\begin{array}{c}\text { Standard } \\
\text { Lanka rubber } \\
\text { /Crepe rubber } \\
\text { / RSS }\end{array}$ & 50 & 400 & $6.5-8.5$ & 100 \\
\hline Tanning industry & $\begin{array}{l}\text { Inland surface } \\
\text { waters }\end{array}$ & 60 & 250 & $5.5-9.0$ & 100 \\
\hline Tamming musuy & $\begin{array}{c}\text { Marine coastal } \\
\text { areas }\end{array}$ & 100 & 300 & $5.5-9.0$ & 150 \\
\hline
\end{tabular}

Source: Herath and Randeni, 2003

RSS: Ribbed Smoked Sheets; CETP: Common Effluent Treatment Plants

According to the data collected, 74, 58 and 62 percent of the factories discharge BOD, COD and TSS levels above the standard set out by the CEA. Therefore, these factories do not comply with the standards in a similar manner with respect to all the pollutants. This is one reason why a simultaneous equation model is proposed in this study. The effluent discharged flow into natural waterways such as rivers and streams on approximately 83 percent of the factories. About 38 percent of the factories have received complaints on water pollution from the people living near these factories. 47 percent of the factories do some form of treatment before water is discharged and 55 percent of these factories who have invested in treatment have also received a complaint. 
The results of the SUR model are given in Table 5. At first glance one would think that these three regressions could be estimated separately. However, on examining the correlation at the bottom of the Table suggests otherwise. The Breusch-Pagan test of independence is significant at $1 \%$ level indicating that error terms correlate with each other. Thus, the use of Seemingly Unrelated Regression technique has significantly improved the efficiency of estimation.

Table 5: Seemingly Unrelated Regression Results

\begin{tabular}{|c|c|c|c|c|c|c|}
\hline \multirow[b]{2}{*}{ Variable } & \multicolumn{2}{|c|}{ BOD } & \multicolumn{2}{|c|}{ COD } & \multicolumn{2}{|c|}{ TSS } \\
\hline & Coef. & $P$ value & Coef. & P value & Coef. & $P$ value \\
\hline Visits & $\begin{array}{r}-1226.0 \\
(2917.3)\end{array}$ & 0.674 & $\begin{array}{r}-1177.6 \\
(5029.8)\end{array}$ & 0.815 & $\begin{array}{r}195.8 \\
(631.1)\end{array}$ & 0.756 \\
\hline $\mathrm{TP}$ & $\begin{array}{r}68.1 \\
(22.57)\end{array}$ & $0.003 * * *$ & $\begin{array}{r}113.4 \\
(38.9)\end{array}$ & $0.004^{*}$ & $\begin{array}{r}15.2 \\
(4.8)\end{array}$ & $0.002 * * *$ \\
\hline Type & $\begin{array}{r}-9465.5 \\
(13910.6)\end{array}$ & 0.496 & $\begin{array}{r}5624.4 \\
(23983.8)\end{array}$ & 0.815 & $\begin{array}{r}9177.5 \\
(3009.5)\end{array}$ & $0.002 * * *$ \\
\hline Complaint & $\begin{array}{r}-19293.8 \\
(9809.8)\end{array}$ & $0.049 * *$ & $\begin{array}{r}-39401.3 \\
(16913.6)\end{array}$ & $0.020 * *$ & $\begin{array}{r}-6113.3 \\
(2122.3)\end{array}$ & $0.004 * * *$ \\
\hline Constant & $\begin{array}{r}5668.8 \\
(9271.2)\end{array}$ & 0.541 & $\begin{array}{r}12294.6 \\
(15984.9)\end{array}$ & 0.442 & $\begin{array}{r}617.2 \\
(2005.8)\end{array}$ & 0.758 \\
\hline R-sq & $\begin{array}{l}.24 \\
\text { Brel }\end{array}$ & -Pagan t & $\begin{array}{r}.22 \\
\text { of indepenc }\end{array}$ & ence: $\operatorname{chi} 2$ & $\begin{array}{r}.37 \\
55.604,\end{array}$ & $=0.0000$ \\
\hline
\end{tabular}

$\mathrm{N}=62$

Note: Figures within parentheses are standard errors

$* * *$ Significant at $1 \% * *$ significant at $5 \%$

Also a test was performed to see whether coefficients of these variables are jointly zero in all the three equations and the results are depicted in Table 6.

Table 6: Test results of joint significance

\begin{tabular}{llll}
\hline Variable & \multicolumn{1}{c}{$\mathbf{H}_{\mathbf{0}}$} & Ch-Sq & Prob>Ch-sq \\
\hline Visits & Coefficient in all three equations $=0$ & 0.55 & 0.9083 \\
TP & Coefficient in all three equations $=0$ & 14.21 & $0.0026^{* * *}$ \\
Type & Coefficient in all three equations $=0$ & 16.05 & $0.0011^{* * *}$ \\
Complaint & Coefficient in all three equations $=0$ & 8.65 & $0.0343^{* *}$ \\
\hline$* * *$ significant at $1 \%$ * $*$ significant at 5\% & &
\end{tabular}

The present system of pollution control in Sri Lanka is through command and control measures. In order to capture the impact of command and control on environmental compliance, the variable 'visits' was included. It gives the number of times officials from the CEA has visited the rubber factory during the year. These visits are expected to make these factories comply with the environmental 
standards. Therefore, one would expect this variable to be significant. Surprisingly, this variable returned non-significant in all three pollutants. As expected, the total production (TP) became highly significant in all three equations. The positive sign indicates that higher the production, higher will be the effluent load. The 'Type' variable too became significant in the joint hypotheses test implying that the factories producing centrifuged latex are significant polluters especially in TSS.

The most significant result of the analysis is the high significance of the 'complaint' variable. This is a dummy variable representing whether the factory concerned has received a complaint from the public. It is interesting to note that it returned a negative sign indicating that the factories who received complaints from public has a lower pollution level in all three pollutants. In fact, factories who have received complaints releases $19293.82 \mathrm{~kg}$ of BOD, $39401.39 \mathrm{~kg}$ of COD and $6113.39 \mathrm{~kg}$ of TSS per year less than that of a firm which has not received a complaint when controlled for quantity of production, type of production and the level of formal pollution control. This is an important finding since non-significant 'visits' variable indicates the failure of the command and control system but the significant 'complaint' variable indicates the possibilities of informal regulation.

Pargal and Wheeler (1996) stated that as scale economies are present, the output elasticity is expected to be significantly less than one. Data in this study also supports this hypothesis. It is observed that when moving from to minimum to maximum of the level of production, the pollution elasticity with respect to levels of production decline indicating the presence of economies of scale (Table 7). This is evident in all three pollutants.

Table 7: Elasticity calculation for total production at different levels in the sample

\begin{tabular}{llllllllll}
\hline \multicolumn{3}{c}{ BOD } & \multicolumn{3}{c}{ COD } & \multicolumn{3}{c}{ TSS } \\
\hline Max & Mean & Min & Max & Mean & Min & Max & Mean & Min \\
24.76 & 1.17 & 0.61 & 9.57 & 1.07 & 0.55 & 4.65 & 1.05 & 0.49 \\
\hline
\end{tabular}

\section{Conclusions}

The data showed that more than 50 percent of the rubber processing factories in Sri Lanka emit pollutants to the environment above the levels prescribed by the Central Environmental Authority of Sri Lanka. There seems to be economies of scale in pollution in this sector as expected. Thus, the general rule of scale economies of abatement is observed in rubber processing sector in Sri Lanka as well. As expected the type of production has a significant impact on pollution loads. Factories producing Centrifuged latex were found to release more pollutants than factories producing Crepe rubber of RSS. 
The most important finding of the study is the potential of informal control in pollution control. The results suggested the minor impact of the present 'command and control' system in pollution control. Instead, informal regulation may be a better option of making factories for the environmental compliance. The coefficient estimates showed that there could be significant reductions in emissions of all three pollutants through informal regulation even when command and control measures are not that effective. CEA should harness this in their programs to curb pollution in the country.

\section{Acknowledgement}

This work has been undertaken with the financial support of the South Asian Network for Development and Environmental Economics (SANDEE) and its sponsors. Technical support and guidance have been provided by several SANDEE resource persons and peers during the course of the research. I am extremely thankful to the Rubber Research Institute of Sri Lanka for their assistance in analyzing wastewater samples and permitting me the use of their laboratory facilities. I especially thank all those rubber producing factories that provided data for this study.

\section{References}

Ranaweera, K. A. H. (1991). "Common industrial pollution issues: the Sri Lankan experience" In: Proceedings of the MEIP in-country workshop, Colombo, Pp. 5-9.

International Rubber Study Group (IRSG) (2007). Rubber Statistical Bulletin, 51(6/7).

Kudaligama, S. (2004). "Effect of rainfall on the pollution problem associated with natural rubber processing: a case study in five factories in the Low Country Wet Zone." Journal of the National Institute of Plantation Management, 20(2)

Dan, N. P., B. X. Thanh and B. D. Truong (2006). "Case studies of groundwater pollution in Southeast Vietnam” International Review for Environmental Strategies, 6(2): 361372.

Yapa, P. A. J. (1984). "Effluent disposal and environmental pollution in rubber plantations in Sri Lanka" In: Proceedings of the International Rubber Conference - "75 Years of Rubber in Sri Lanka", Colombo, 17-19 September, 381-390.

Edirisinghe, J. C., S. Siriswardana and P. Prasandith, P. (2008). "Taxing the pollution: the case reducing the environmental impact of rubber production in Sri Lanka". Working Paper No 30-08, South Asian Network for Development and Environmental Economics (SANDEE).

Murty, M. N., S. Kumar and M. Paul (2001). "Environmental regulation, productive efficiency and cost of pollution abatement: a case study of sugar industry in India" Institute of Economic Growth, Delhi. 
Goldar, B. and R. Pandey (2001). "Water pricing and abatement of industrial water pollution: study of distilleries in India" Environmental Economics and Policy Studies 4: 95 - 113.

Dasgupta, S., M. Huq, D. Wheeler and C. Zhang (1996). "Water pollution abatement by Chinese industry: cost estimates and policy implications" Applied Economics, 33(4): 547 - 557.

Pargal, S. and D. Wheeler (1996). "Informal regulation of industrial pollution in developing countries: evidence from Indonesia" Journal of Political Economy, 104(6)

Huq, M. and D. Wheeler (1993). "Pollution reduction without formal regulation: evidence from Bangladesh" World Bank Working Paper 1993-39, World Bank, Washington DC.

Hartman, R. S., M. Huq and D. Wheeler (1997). "Why paper mills clean up: determinants of pollution abatement in four Asian countries" Policy Research Working Paper 1710 World Bank, Washington DC.

Kathuria, V. (2004). "Informal regulation of pollution in a developing country: empirical evidence from India" Working Paper No. 6-04. South Asian Network for Development and Environmental Economics (SANDEE)

Zellner, A. (1962). "An efficient method of estimating seemingly unrelated regressions and tests of aggregation bias" Journal of the American Statistical Association 57: 500509.

Herath, H. M. B. S. and R. P. L. C. Randeni (2003). "Pollution control in industrial estates in Sri Lanka: private sector participation for sustained environmental performance" (http://www.idrc.ca/en/ev-43181-201-1-DO_TOPIC.html) [accessed on 6/12/2006].

Wooldridge, J. M. (2001). "Econometric analysis of cross section and panel data" The MIT Press, Cambridge, Massachusetts, London, England. 